Jurnal Ilmu Ilmu Agribisnis: Journal of Agribusiness Science, 9(2), Mei 2021

\title{
PARTISIPASI PETANI ANGGOTA PERKUMPULAN PETANI PEMAKAI AIR (P3A) DALAM PENGELOLAAN AIR IRIGASI DI KECAMATAN PALAS KABUPATEN LAMPUNG SELATAN
}

\author{
(The Participation Farmers of Membership Water User Farmers in Irrigation Water Management in \\ Kecamatan Palas, Lampung Selatan District)
}

Wida Alviyanti, Indah Nurmayasari, Fembriarti Erry Prasmatiwi

Jurusan Agribisnis, Fakultas Pertanian, Universitas Lampung, Jl. Prof. Dr. Soemantri Brodjonegoro No.1

Bandar Lampung 35145, e-mail: indah.nurmayasari@fp.unila.ac.id

\begin{abstract}
Rice farmers uses irrigation water managed through Water User Association (P3A). This study aims to analyze rice farming income, the level of participation, and factors related to the participation of farmers members of the P3A. Research data were collected in Palas Subdistrict, South Lampung Regency in November - December 2019. The number of respondents was 68 rice farmers members who were randomly selected. Primary data were obtained by interviewing the respondents and secondary data were obtained from several related institutions. The data were analyzed descriptively and using Rank Spearman correlation test. The results showed that rice farming in planting season 1 and 2 are profitable to cultivate. The levels of participation of P3A members in planning activities, implementing activities, monitoring and evaluating activities, and utilizing the results are in high category. The factors related to the participation of P3A members on irrigation management were the intensity of farmer interaction, the level of motivation, and land size.
\end{abstract}

Key words: participation, Water User Association

\section{PENDAHULUAN}

Subsektor tanaman pangan merupakan salah satu subsektor yang berperan sangat penting dalam mewujudkan ketahanan pangan nasional. Dalam memperkuat ketahanan pangan perlu adanya pengembangan di sektor pertanian terutama pada subsektor tanaman pangan melalui peningkatan produktivitas komoditas tanaman pangan. Salah satu komoditas tanaman pangan yang mempunyai peranan sangat penting dalam mewujudkan ketahanan pangan adalah komoditas padi.

Pada tahun 2016 Provinsi Lampung menjadi salah satu provinsi penghasil komoditas padi dengan luas lahan 90.450 ha, produksi 494.625 ton, dan produktivitas 5,47 ton/ha. Tahun 2017 luas lahan mencapai 106.058 ha, produksi 579.534 ton, serta produktivitas 5,46 ton/ha (BPS Provinsi Lampung 2018). Kabupaten Lampung Selatan adalah salah satu kabupaten yang potensial untuk usahatani padi dengan lahan terluas dan tingkat produksi terbesar di Provinsi Lampung. Kabupaten Lampung Selatan memiliki luas lahan 17.657 ha dengan produksi 97.060 ton dan produktivitas 5,50 ton/ha. Menurut BPS Kabupaten Lampung Selatan (2018), Kecamatan Palas memiliki lahan terluas dan tingkat produksi terbesar di Kabupaten Lampung
Selatan berturut-turut yaitu 14.448 ha dan produksi 81.272 ton pada tahun 2016 sedangkan pada tahun 2017 mengalami peningkatan berturut-turut 17.657 ha dan 97.606 ton.

Peningkatan produksi padi di Kecamatan Palas tidak terlepas dari peran Dinas Pertanian Kabupaten Lampung Selatan. Berbagai sarana dan prasarana pertanian yang dibutuhkan terus diupayakan oleh pemerintah Kabupaten Lampung Selatan melalui berbagai program bantuan untuk petani, salah satunya melalui pembangunan sistem irigasi untuk pengelolaan usahatani padi di Kecamatan Palas. Pembangunan sistem irigasi didasari pada permasalahan akan ketersediaan sumberdaya air dan sumberdaya lahan yang semakin terbatas. Kondisi ini menyebabkan berbagai konflik dalam pemanfaatan sumberdaya air, maka perlu adanya peningkatan kemampuan sumberdaya manusia untuk mengelola sumberdaya air secara berkelanjutan. Undang-undang No. 7 tahun 2004 tentang Sumberdaya Air dan Peraturan Pemerintah No. 20 tahun 2006 tentang Irigasi, menyatakan bahwa tanggung jawab pengelolaan jaringan irigasi tersier dan jaringan irigasi kwarter sampai ke tingkat usahatani menjadi hak dan tanggung jawab petani yang terhimpun dalam wadah Perkumpulan Petani Pemakai Air (P3A) 
sesuai dengan kemampuannya. Berdasarkan hal tersebut, pengelolaan sistem irigasi di Kabupaten Lampung Selatan dilakukan oleh P3A mulai dari perencanaan hingga pelaksanaan.

Dibentuknya kelembagaan P3A merupakan salah satu upaya pemerintah dalam peningkatan produksi pertanian. Petani yang tergabung dalam organisasi P3A akan memperoleh keuntungan berupa pemerataan ketersediaan sumber air bagi pengelolaan usahatani guna meningkatkan produktivitas dan produksi pertanian sehingga berdampak pada peningkatan pendapatan. Selain itu, pemanfaatan sumber air juga merupakan faktor penting dalam proses pertumbuhan tanaman, namun kebutuhannya harus disesuaikan dengan jenis komoditas yang ditanam. Adanya pengelolaan air irigasi pada P3A di Kecamatan Palas diharapkan anggota P3A dapat berpartisipasi dalam menghitung kebutuhan air bagi komoditas padi sehingga dapat kebutuhan air tercukupi.

Partisipasi anggota dari masing-masing organisasi P3A sangat dibutuhkan di setiap kegiatan yang dilakukan agar sesuai dengan tujuan yang ingin dicapai. Partisipasi anggota kelompok tani dilihat dari bagaimana anggota P3A mengikuti kegiatan atau program penyuluhan yang dilakukan. Partisipasi yang baik dari anggota P3A tersebut akan mempengaruhi produksi dan pendapatan usahatani padi. Berdasarkan uraian tersebut tujuan penelitian ini adalah mengetahui pendapatan usahatani, tingkat partisipasi petani, serta faktorfaktor yang berhubungan dengan partisipasi petani.

\section{METODE PENELITIAN}

Metode yang digunakan dalam penelitian ini adalah metode survei. Penelitian ini dilakukan di Desa Bandan Hurip dan Pulau Tengah, Kecamatan Palas, Kabupaten Lampung Selatan. Lokasi penelitian ini ditentukan secara purposive dengan pertimbangan desa tersebut merupakan desa yang melaksanakan program P3A. Responden yang digunakan pada penelitian ini adalah petani padi anggota P3A.

Jumlah sampel ditentukan secara proporsional tiap desa dengan menggunakan rumus dari Sugiyono (2007) dimana jumlah anggota Gapoktan yaitu 708 petani. Jumlah populasi petani anggota P3A di Desa Bandan Hurip terdiri dari 471 petani, dan di Desa Pulau Tengah terdiri dari 237 petani. Berdasarkan perhitungan dengan menggunakan rumus Sugiarto, et al. (2003), diperoleh jumlah sampel sebanyak 68 petani yang juga langsung sebagai responden penelitian. Pengambilan data dilakukan pada bulan November hingga Desember 2019.

Menurut Soekartawi (2006) analisis pendapatan usahatani padi dihitung dari selisih pendapatan total dengan biaya total dari usahatani tersebut, secara matematis ditulis sebagai berikut :

$\pi=\mathrm{TR}-\mathrm{TC}$

$\pi=(\mathrm{Q} . \mathrm{PQ})-(\mathrm{FC}+\mathrm{VC})$.

$$
\begin{aligned}
& \text { Keterangan: } \\
& \begin{array}{ll}
\pi & =\text { Pendapatan usahatani padi }(\mathrm{Rp}) \\
\mathrm{TR} & =\text { Total penerimaan }(\mathrm{Rp}) \\
\mathrm{TC} & =\text { Total biaya }(\mathrm{Rp}) \\
\mathrm{Q} & =\text { Produksi }(\mathrm{kg}) \\
\mathrm{PQ} & =\text { Harga }(\mathrm{Rp} / \mathrm{kg}) \\
\mathrm{FC} & =\text { Biaya tetap }(\mathrm{Rp}) \\
\mathrm{VC} & =\text { Biaya variabel }(\mathrm{Rp})
\end{array}
\end{aligned}
$$

Untuk mengetahui usahatani padi menguntungkan atau tidak, dilakukan analisis penerimaan dan biaya $(\mathrm{R} / \mathrm{C})$ sebagai berikut :

$\mathrm{R} / \mathrm{C}=\frac{\mathrm{TR}}{\mathrm{TC}}$

Jika $\mathrm{R} / \mathrm{C}>1$, maka usaha mengalami keuntungan Jika $\mathrm{R} / \mathrm{C}=1$, maka usahatani impas.

Jika $\mathrm{R} / \mathrm{C}<1$, maka usaha mengalami kerugian.

Analisis tingkat partisipasi petani padi Anggota P3A yaitu menggunakan analisis deskriptif dengan melihat partisipasi petani dalam program P3A dari aspek perencanaan, pelaksanaan, penilaian, dan pemanfaatan program. Faktor-faktor yang berhubungan dengan partisipasi petani padi dianalisis dengan uji korelasi menggunakan korelasi Spearman's Rho. Faktor-faktor yang diduga berhubungan dengan partisispasi petani padi pada penelitian ini adalah tingkat pengetahuan $\left(\mathrm{X}_{1}\right)$, intensitas interaksi petani $\left(\mathrm{X}_{2}\right)$, tingkat motivasi $\left(\mathrm{X}_{3}\right)$, luas lahan $\left(\mathrm{X}_{4}\right)$, dan pendapatan $\left(\mathrm{X}_{5}\right)$.

\section{HASIL DAN PEMBAHASAN}

\section{Keadaan Umum Responden}

Umur petani padi anggota P3A berkisar antara 2863 tahun dengan rata-rata umur petani 48 tahun. Pekerjaan sampingan yang masih berkaitan dengan budidaya pertanian (on farm) sebanyak 4,41 persen yaitu kegiatan usahatani padi sawah dan juga petani duku. Pekerjaan di luar kegiatan usahatani tetapi masih berkaitan dengan pertanian yang 
dilakukan oleh petani atau anggota keluarga seperti buruh tani (off farm) pada petani responden sebanyak 7,35 persen sebagai buruh tani. Pekerjaan diluar kegiatan pertanian (non farm) pada petani responden yaitu buruh bangunan, ojek, pedagang, supir, guru, wiraswasta, buruh, dan peternak. Petani responden lainnya tidak memiliki pekerjaan sampingan yaitu sebanyak 36 responden dengan persentase sebesar 52,94 persen. Rata-rata luas lahan petani padi responden adalah 0,81 hektar. Sebagian besar petani padi memiliki luas lahan berkisar 0,25 - 0,83 hektar dengan persentase sebesar 60,29 persen. Status kepemilikan lahan petani padi responden adalah milik sendiri.

\section{Penggunaan Sarana Produksi}

Sarana produksi yang digunakan pada usahatani padi adalah benih, pupuk, pestisida, tenaga kerja, dan peralatan. Penggunaan benih padi dalam 1 ha mencapai $30 \mathrm{~kg}$. Harga benih padi mengalami kenaikan pada MT II mencapai Rp14.500,00/kg. Pada MT I (rendeng), petani menggunakan benih cimalaya muncul sedangkan pada MT II (gadu) menggunakan benih ciherang. Pupuk yang digunakan adalah pupuk urea, SP36, NPK, dan $\mathrm{KCl}$. Pestisida yang digunakan adalah rodiamin dan spontan dengan rincian yang dapat dilihat pada Tabel 1. Tenaga kerja yang digunakan yaitu tenaga kerja luar keluarga (TKLK) dan dalam keluarga (TKDK) yang diukur setara hari orang kerja (HOK) dengan upah Rp70.000,00 per hari. TKLK yang digunakan pada MT I dan MT II adalah 65,92 HOK, sedangkan untuk TKDK yaitu 14 HOK. Biaya TKLK yang dikeluarkan untuk tenaga kerja sebesar Rp4.614.560,00 per hektar.

\section{Produksi dan Penerimaan}

Produksi yang dihasilkan pada MT 1 lebih tinggi daripada MT II secara berturut-turut adalah 7358 $\mathrm{kg}$ dan $6957 \mathrm{~kg}$. Harga jual padi yang diterima petani dapat dikatakan fluktuatif berkisar antara Rp3.800,00/kg - Rp4.500,00/kg. Pada Tabel 1 menjelaskan bahwa rata-rata penerimaan petani padi per hektar pada MT I dan MT II sebesar Rp27.961.873,00 dan Rp31.307.189,00.

\section{Analisis Pendapatan Usahatani Padi}

Pendapatan usahatani padi adalah selisih antara total penerimaan dengan total biaya produksi yang dikeluarkan dalam satu musim. Pendapatan usahatani padi dibedakan menjadi pendapatan atas biaya tunai dan pendapatan atas biaya total. Rata- rata penerimaan, biaya, dan pendapatan pada MT I dan MT II disajikan pada Tabel 1.

Penelitian ini meneliti dua musim tanam padi dengan rata-rata penerimaan, biaya, dan pendapatan MT I dan MT II disajikan pada Tabel 1. Total penerimaan MT I per hektar pada usahatani padi di daerah penelitian ini sebesar Rp27.961.873,00 dengan total biaya Rp15.912.719,00. Pada MT II memiliki nilai penerimaan lebih tinggi daripada MT 1 yaitu sebesar Rp31.307.189,00. Nisbah penerimaan atas biaya total (RC ratio) pada MT 1 dan MT II ini diperoleh nilai $\mathrm{R} / \mathrm{C}$ lebih dari 1 , artinya usahatani padi di daerah penelitian pada 2 musim ini menguntungkan. Produksi padi di MT I lebih tinggi daripada MT II dengan nilai selisih 401 $\mathrm{kg} / \mathrm{ha}$. Biaya yang dikeluarkan petani pada MT II lebih tinggi daripada MT I, dikarenakan adanya biaya lain-lain yang dibebankan pada biaya irigasi sebesar Rp2.013.435,00. Hal ini dapat dipengaruhi oleh perbedaan musim dan harga jual padi di daerah penelitian di setiap musim panen. Pada MT I dilakukan pada saat musim rendeng, di mana produksi tinggi dan harga jual rendah. Harga jual turun dikarenakan ketersediaan padi yang lebih banyak akibat panen raya. Kondisi padi yang basah saat panen memengaruhi harga jual padi.

\section{Tingkat Partisipasi Petani}

Partisipasi merupakan keikutsertaan sekelompok orang atau anggota dalam suatu kegiatan yang meliputi perencanaan, pelaksanaan, pemantauan dan evaluasi, serta pemanfaatan program. Pada penilaian skor indikator tersebut terdapat tiga kategori penilaian, yaitu 3 (sering mengikuti), 2 (cukup mengikuti), dan 1 (jarang mengikuti). Rekapitulasi skor penilaian beberapa indikator partisipasi pada Tabel 2. Pada Tabel 2, dapat dilihat bahwa nilai skor partisipasi terbesar terdapat pada perencanaan kegiatan dengan ratarata petani anggota yang sering mengikuti adalah 50 orang. Partisipasi petani dalam pelaksanaan kegiatan P3A cukup baik, dapat dilihat dari seringnya petani mengikuti kegiatan P3A dengan rata-rata 45 orang petani. Tingkat partisipasi dalam penilaian dan evaluasi program P3A juga sering dilakukan petani dengan rata-rata 41 orang petani, sedangkan partisipasi petani dalam pemanfaatan kegiatan $\mathrm{P} 3 \mathrm{~A}$ rata-rata 48 orang petani. Berdasarkan hasil penilaian skor tersebut dapat digolongkan menjadi tiga klasifikasi yang terangkum dalam Tabel 3, yaitu rekapitulasi tingkat partisipasi anggota dalam program $\mathrm{P} 3 \mathrm{~A}$. 
Tabel 1. Rata-rata penerimaan, biaya, dan pendapatan usahatani padi MT I dan MT II di Kecamatan Palas Kabupaten Lampung Selatan, tahun 2019

\begin{tabular}{|c|c|c|c|c|c|c|c|}
\hline \multirow[b]{2}{*}{ Uraian } & \multicolumn{4}{|c|}{ MT I } & \multicolumn{3}{|c|}{ MT II } \\
\hline & Satuan & Jumlah & Harga (Rp) & Nilai (Rp) & Jumlah & Harga (Rp) & Nilai (Rp) \\
\hline \multicolumn{8}{|l|}{ Penerimaan } \\
\hline Produksi MT 1 & $\mathrm{Kg}$ & $7.358,39$ & $3.800,00$ & $27.961 .873,64$ & $6.957,15$ & $4.500,00$ & $31.307 .189,54$ \\
\hline \multicolumn{8}{|l|}{ Biaya Produksi } \\
\hline \multicolumn{8}{|l|}{ I.Biaya Tunai musim } \\
\hline Benih & $\mathrm{Kg}$ & 30,07 & $14.558,82$ & $437.848,42$ & 30,07 & $14.558,82$ & $437.848,32$ \\
\hline P.Urea & $\mathrm{Kg}$ & 170,22 & $1.851,76$ & $315.200,07$ & 165,22 & $1.851,76$ & $305.953,92$ \\
\hline P. SP36 & $\mathrm{Kg}$ & 75,34 & $2.900,00$ & $218.500,36$ & 76,25 & $2.900,00$ & $221.132,90$ \\
\hline P. NPK & $\mathrm{Kg}$ & 97,20 & $2.680,77$ & $260.568,60$ & 95,77 & $2.050,00$ & $196.328,07$ \\
\hline P. $\mathrm{KCl}$ & $\mathrm{Kg}$ & 85,33 & $5.388,89$ & $459.860,66$ & 86,61 & $4.992,65$ & $432.406,54$ \\
\hline \multicolumn{8}{|l|}{ Pestisida } \\
\hline Rodiamin cair & Ltr & 1,00 & $60.000,00$ & $59.912,85$ & 1,04 & $60.000,00$ & $62.500,00$ \\
\hline rodiamin bubuk & $\mathrm{Bks}$ & 7,39 & $95.000,00$ & $701.978,94$ & 7,39 & $95.000,00$ & $701.978,94$ \\
\hline Spontan & Ltr & 1,00 & $120.000,00$ & $119.825,71$ & 1,04 & $120.000,00$ & $125.000,00$ \\
\hline TKLK & $\mathrm{HOK}$ & 65,92 & $70.000,00$ & $4.614 .560,64$ & 65,92 & $70.000,00$ & $4.614 .560,64$ \\
\hline PBB & $\mathrm{Rp}$ & & & $157.588,96$ & & & $157.588,96$ \\
\hline biaya poktan MT 1 & $\mathrm{Rp}$ & & & $37.037,04$ & & & $37.037,04$ \\
\hline biaya irigasi & $\mathrm{Rp}$ & & & 0,00 & & & $2.013 .435,00$ \\
\hline Total Biaya Tunai & & & & $7.382 .882,25$ & & & $9.305 .770,33$ \\
\hline \multicolumn{8}{|c|}{ II.Biaya diperhitungkan } \\
\hline Sewa Lahan & $\mathrm{ha} / \mathrm{mt}$ & 1,00 & $7.500 .000,00$ & $7.500 .000,00$ & & & $7.500 .000,00$ \\
\hline TKDK 1 & HOK & 14,00 & $70.000,00$ & $980.000,00$ & & & $980.000,00$ \\
\hline Penyusutan Alat & $\mathrm{Rp}$ & & & $49.837,11$ & & & $61.527,29$ \\
\hline \multicolumn{2}{|c|}{ Total Biaya diperhitungkan } & & & $8.529 .837,11$ & & & $8.541 .527,29$ \\
\hline III.Total Biaya & & & & $15.912 .719,36$ & & & $17.847 .297,62$ \\
\hline \multicolumn{8}{|l|}{ Pendapatan } \\
\hline \multicolumn{3}{|c|}{ I.Pendapatan Atas Biaya Tunai } & & $20.578 .991,39$ & & & $22.001 .419,21$ \\
\hline \multicolumn{3}{|c|}{ II. Pendapatan Atas Biaya Total } & & $12.049 .154,28$ & & & $13.459 .891,92$ \\
\hline \multicolumn{3}{|c|}{$\mathrm{R} / \mathrm{C}$ atas biaya tunai } & & 3,79 & & & 3,36 \\
\hline \multicolumn{2}{|l|}{$\mathrm{R} / \mathrm{C}$ atas biaya total } & & & 1,76 & & & 1,75 \\
\hline
\end{tabular}

Berdasarkan Tabel 3 hasil penilaian tingkat partisipasi anggota P3A dapat dibagi dalam tiga klasifikasi yaitu rendah (20-23), sedang (34-47), dan tinggi (48-61). Tingkat partisipasi dalam perencanaan kegiatan, pelaksanaan kegiatan, pemantauan dan evaluasi kegiatan, serta pemanfaatan hasil kegiatan program P3A di Desa Bandan Hurip dan Desa Pulau Tengah termasuk dalam klasifikasi tinggi dengan persentase 97,06 persen. Kurangnya partisipasi anggota tersebut karena pengurus kurang melibatkan seluruh anggota dalam semua tahapan program.

Tabel 3. Rekapitulasi tingkat partisipasi anggota dalam program $\mathrm{P} 3 \mathrm{~A}$

\begin{tabular}{cccr}
\hline $\begin{array}{c}\text { Selang } \\
\text { (Skor) }\end{array}$ & Klasifikasi & $\begin{array}{c}\text { Jumlah } \\
\text { Petani (orang) }\end{array}$ & $\begin{array}{c}\text { Persentase } \\
(\%)\end{array}$ \\
\hline $20-23$ & Rendah & 0 & 0 \\
$34-47$ & Sedang & 2 & 2,94 \\
$48-61$ & Tinggi & 66 & 97,06 \\
\hline Jumlah & & 68 & 100,00 \\
\hline Rata-rata : & 44,12 (Tinggi) & & \\
\hline
\end{tabular}

\section{Faktor-Faktor yang Berhubungan dengan Partisipasi Petani P3A}

Faktor-faktor yang berhubungan dengan partisipasi petani anggota P3A dalam pengelolaan air irigasi yang digunakan dalam penelitian ini adalah tingkat pengetahuan $\left(\mathrm{X}_{1}\right)$, intensitas interaksi petani $\left(\mathrm{X}_{2}\right)$, tingkat motivasi $\left(\mathrm{X}_{3}\right)$, luas lahan $\left(\mathrm{X}_{4}\right)$, dan pendapatan $\left(\mathrm{X}_{5}\right)$. Secara garis besar faktor-faktor tersebut dapat dijelaskan sebagai berikut.

\section{Tingkat Pengetahuan Petani Anggota P3A $\left(X_{1}\right)$}

Tingkat pengetahuan petani anggota P3A merupakan salah satu yang diketahui yang diperoleh melalui panca indra sehingga dapat mengetahui beberapa aspek melalui kegiatan pengelolaan air irigasi dari mengetahui pengertian kegiatan, tujuan kegiatan, manfaat pengelolaan air irigasi, cara pengelolaan air irigasi, dan siapa yang telah menjadi tenaga pengajarnya. Tingkat pengetahuan petani tentang P3A $(76,47 \%)$ 
tergolong tinggi. Hal ini menunjukkan bahwa petani anggota mengetahui dengan baik semua aspek pengelolaan air irigasi sebagai sistem pengairan untuk mengatur ketersediaan pasokan air dalam usahatani dimulai dari penanaman hinhgga panen. Kegiatan pengelolaan air irigasi ini dilakukan oleh kelompok tani dengan tujuan untuk memberikan efisiensi penggunaan air dalam meminimalisir biaya yang dikeluarkan oleh petani. Petani cukup mengetahui manfaat lain dari kegiatan ini yaitu meningkatkan kesuburan tanah dengan mengalirkan air dan lumpur yang mengandung unsur hara.

\section{Tingkat Intensitas Interaksi Anggota P3A $\left(\mathrm{X}_{2}\right)$}

Interaksi anggota P3A merupakan hubungan atau proses komunikasi yang terjadi antar anggota, pengurus, penyuluh, tokoh masyarakat dan pihak lain dalam kegiatan pengelolaan air irigasi. Sebanyak 68 petani responden memiliki intensitas interaksi petani anggota P3A tergolong tinggi, dengan skor sebesar 83,83 persen. Intensitas interaksi anggota P3A dapat diketahui dari seberapa sering komunikasi atau diskusi yang dilakukan oleh anggota mengenai kegiatan pengelolaan air.

\section{Tingkat Motivasi $\left(\mathbf{X}_{3}\right)$}

Tingkat motivasi merupakan dorongan dari luar dan dari dalam diri petani untuk bertindak melakukan sesuatu sehingga mencapai tujuan tertentu. Dorongan dapat dilihat dari siapa saja yang memberikan motivasi dari lingkup keluarga dan juga dapat dilihat dari siapa saja yang melakukan dan memberikan motivasi lingkungan sekitar. Tingkat motivasi petani anggota P3A berada pada klasifikasi tinggi dengan skor sebesar 75,06 persen. Petani cukup termotivasi dengan adanya sosialisasi yang dilakukan oleh penyuluh terkait dengan program P3A untuk meningkatkan produksi dan pendapatan petani. Petani memiliki motivasi yang cukup tinggi yang didukung pula oleh keluarga dalam mencapai tujuan dari program P3A. Petani juga rela mengorbankan tenaga, pikiran, waktu, dan biaya untuk mengikuti program tersebut.

\section{Luas Lahan $\left(\mathbf{X}_{4}\right)$}

Salah satu faktor yang dapat mempengaruhi partisipasi petani anggota P3A dalam pengelolaan irigasi adalah luas lahan. Luas lahan merupakan areal atau tempat yang digunakan untuk melakukan usahatani yaitu sebidang tanah yang diukur dengan satuan hektar (ha) dengan status lahan yang digarap oleh para petani. Pada status kepemilikan lahan petani juga dilakukan pengambilan skor nilai, dengan 3 untuk hak milik, 2 untuk sewa, dan 1 untuk bagi hasil. Klasifikasi tertinggi pada luas lahan sebesar 86,77 persen dan kepemilikan lahan petani anggota $\mathrm{P} 3 \mathrm{~A}$ di daerah penelitin adalah hak milik.

\section{Tingkat Pendapatan $\left(\mathbf{X}_{5}\right)$}

Pendapatan merupakan penerimaan bersih usahatani padi yang akan didapat setelah dikurangi biaya-biaya (peralatan, pupuk, pestisida, dan tenaga kerja) sehingga diperoleh pendapatan bersih usahatani dan dapat dilihat per (ha). Tingkat pendapatan petani anggota $\mathrm{P} 3 \mathrm{~A}$ tergolong tinggi yaitu sebesar 83,82 persen dengan jumlah responden 57 orang. Rata-rata tingkat pendapatan petani anggota P3A adalah Rp20.235.000,00. Persentase responden yang memiliki klasifikasi rendah adalah 4,41 persen, hal tersebut salah satunya dapat dikarenakan luas lahan yang digunakan beberapa petani cukup sempit $(<0,5$ ha). Fluktuasi pendapatan usahatani padi ini dapat dipengaruhi oleh biaya-biaya yang dikeluarkan oleh petani lebih tinggi, misalnya pada biaya peralatan, sarana produksi, dan biaya tenaga kerja. Hal ini sejalan dengan hasil penelitian Maulidiawati, Nikmatullah, dan Prayitno (2018) bahwa partisipasi petani tidak berhubungan nyata dengan pendapatan usahatani.

\section{Analisis Faktor-faktor yang Berhubungan dengan Tingkat Partisipasi Anggota P3A dalam Pengelolaan Air Irigasi}

Faktor-faktor yang berhubungan dengan tingkat partisipasi petani anggota $\mathrm{P} 3 \mathrm{~A}$ dalam pengelolaan air irigasi yang digunakan dalam penelitian ini diambil dari berbagai pendapat dan hasil penelitian, diantaranya mengacu pada pendapat hasil penelitian Suroso (2014) yaitu : (1) tingkat pengetahuan tentang program, (2) interaksi petani anggota, (3) motivasi petani, (4) Luas lahan, dan (5) tingkat pendapatan

Variabel $\mathrm{X}$ yang digunakan pada analisis ini adalah tingkat pengetahuan $\left(\mathrm{X}_{1}\right)$, intensitas interaksi petani $\left(\mathrm{X}_{2}\right)$, tingkat motivasi $\left(\mathrm{X}_{3}\right)$, luas lahan $\left(\mathrm{X}_{4}\right)$, dan pendapatan $\left(X_{5}\right)$. Variabel $X_{2}, X_{3}$, dan $X_{4}$ berhubungan nyata dengan partisipasi anggota $\mathrm{P} 3 \mathrm{~A}$, sedangkan $\mathrm{X}_{1}$ dan $\mathrm{X}_{5}$ tidak berhubungan nyata dengan partisipasi petani. 
Tabel 2. Sebaran responden berdasarkan skor indikator partisipasi petani anggota dalam program P3A

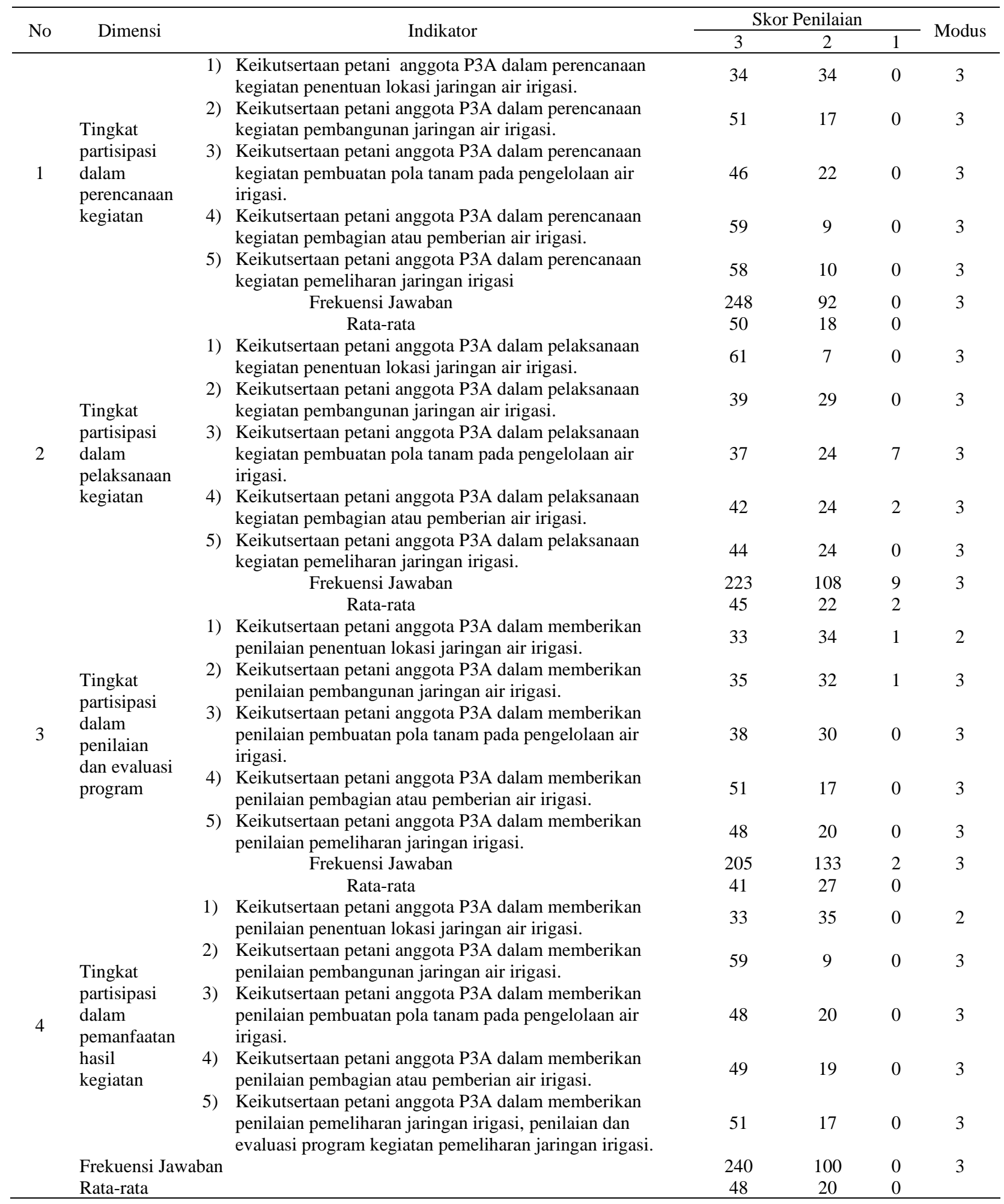

\section{Hubungan antara Tingkat Pengetahuan dengan Tingkat Partisipasi Petani Anggota P3A}

Variabel tingkat pengetahuan tidak hubungan nyata dengan tingkat partisipasi petani. Tingkat pengetahuan menjadi faktor yang tidak berarti karena tingkat pengetahuan petani anggota P3A dalam program $\mathrm{P} 3 \mathrm{~A}$ tidak berhubungan nyata karena meskipun anggota mengetahui tentang program-program dalam $\mathrm{P} 3 \mathrm{~A}$, namun kontribusi dan partisipasi petani dalam program ini sangatlah kurang. Hasil penelitian ini sejalan dengan penelitian Antika, Nikmatullah, dan Prayitno (2017), yang menyatakan bahwa tingkat 
pengetahuan yang tinggi tidak memengaruhi tingkat partisipasi petani dalam melakukan program pengelolaan air irigasi.

\section{Hubungan antara Intensitas Interaksi Petani dengan Tingkat Partisipasi Petani Anggota P3A}

Interaksi petani hubungan nyata dengan tingkat partisipasi petani dalam pengelolaan air irigasi yang ditunjukkan dengan signifikansi 0,000 dan nilai koefisien korelasi 0,808 . Nilai koefisien korelasi intensitas interaksi petani positif, artinya apabila intensitas interaksi petani naik maka tingkat partisipasi akan naik. Interaksi petani menjadi faktor yang cukup berpengaruh terhadap tingkat partisipasi petani karena masyarakat memiliki hubungan interaksi yang baik satu sama lain sehingga interaksi yang terbentuk mampu mendorong setiap petani untuk berpartisipasi dalam pengelolaan air irigasi. Hal ini sejalan dengan penelitian Antika, Nikmatullah, dan Prayitno (2017) bahwa masyarakat dengan interaksi tertentu mempunyai kecenderungan memiliki aktivitas partisipasi pula.

\section{Hubungan antara Tingkat Motivasi dengan Tingkat Partisipasi Petani Anggota P3A}

Tingkat motivasi berhubungan nyata dengan tingkat partisipasi petani anggota P3A dilihat dari nilai signifikansi 0,000 dan nilai koefisien korelasi 0,708. Nilai koefisien korelasi tingkat motivasi petani positif, artinya apabila tingkat motivasi petani naik maka tingkat partisipasi akan naik. Motivasi petani yang beragam menjadi faktor pendorong yang cukup baik, motivasi untuk meningkatkan produksi lahannya menjadi salah satu alasan yang cukup kuat untuk petani. Petani beranggapan bahwa ketika ikut berpartisipasi dalam pengelolaan irigasi yang baik dapat meningkatkan produksinya arena lahan memperoleh air yang cukup untuk berproduksi. Hal ini sejalan dengan penelitian (Triana, Rangga, dan Viantimala 2017) yang menyatakan bahwa tingkat motivasi berhubungan nyata dengan tingkat partisipasi.

\section{Hubungan antara Luas Lahan dengan Tingkat Partisipasi Petani Anggota P3A}

Variabel luas lahan menunjukan hubungan yang nyata dengan tingkat partisipasi petani. Nilai signifikansi yang diperoleh yaitu 0,037 dan nilai koefisien korelasi $-0,253$. Nilai koefisien korelasi luas lahan petani positif, artinya apabila luas lahan petani naik maka tingkat partisipasi akan naik.
Luas lahan menjadi faktor yang berhubungan dengan tingkat partisipasi petani karena luasan lahan yang dimilki oleh petani memerlukan pengairan yang baik untuk tetap berproduksi dengan baik. Luas lahan menjadi faktor yang kurang berarti dalam partisipasi petani karena petani anggota tidak seluruhnya memiliki jumlah lahan yang luas, namun setiap petani anggota ingin mencapai keberhasilan dalam usahataninya sehingga mereka berpartisipasi aktif guna pengelolaan air irigasi yang lebih baik untuk menunjang usahataninya. Hal ini sejalan dengan penelitian Yama, Gitosaputro, dan Hasanudin (2018) bahwa luas lahan memiliki pengaruh nyata terhadap tingkat partisipasi petani.

\section{Hubungan antara Tingkat Pendapatan dengan Tingkat Partisipasi Petani Anggota P3A}

Hasil pengujian yang dilakukan menunjukkan bahwa nilai signifikansi yang diperoleh sebesar 0,788 , artinya tingkat pendapatan tidak memiliki hubungan yang nyata terhadap tingkat partisipasi anggota P3A di daerah penelitian. Tingkat pendapatan yang diperoleh petani memiliki nilai rata-rata sebesar Rp20.235.451,00 per hektar. Apabila ada program P3A seperti perbaikan jaringan tersier dan jaringan sekunder yang rusak atau bahkan penambahan jaringan tersier maka setiap anggota diwajibkan tanpa terkecuali untuk membayar iuran beberapa uang, material seperti semen, batu, pasir atau kayu dan tenaga untuk bergotong royong mengerjakannya. Bagi anggota yang pendapatannya kecil dapat membayar iuran berupa pasir atau batu yang dapat diperoleh dari sungai tanpa harus membeli, cukup dengan modal tenaga dan kemauan, sedangkan untuk anggota yang pendapatannya besar, biasanya mereka membayar iuran berupa uang atau semen. Namun untuk iuran wajib berupa uang, ditetapkan sebesar Rp30.000,00 per orang, baik bagi anggota yang berpendapatannya kecil maupun yang memiliki pendapatan yang besar. Hasil penelitian ini tidak sejalan dengan penelitian sebelumnya yang dilakukan Kasogi, Lestari, dan Rosanti (2014) yang menyimpulkan bahwa tingkat partisipasi kelompok tani dipengaruhi oleh tingkat pendapatan yang diperoleh petani padi tersebut.

\section{KESIMPULAN}

Berdasarkan hasil penelitian, pendapatan petani padi atas biaya total pada MT I dan MT II sebesar Rp12.049.000,00 dan Rp13.459.000,00. Tingkat partisipasi anggota P3A dalam pengelolaan air irigasi di Kecamatan Palas Lampung Selatan 
tergolong tinggi mulai dari perencanaan kegiatan, pelaksanaan kegiatan, penilaian dan evaluasi program serta pemanfaatan hasil kegiatan. Faktorfaktor yang berhubungan dengan tingkat partisipasi petani padi anggota $\mathrm{P} 3 \mathrm{~A}$ dalam pengelolaan irigasi adalah intensitas interaksi petani, tingkat motivasi, dan luas lahan memiliki hubungan yang nyata terhadap tingkat partisipasi.

\section{DAFTAR PUSTAKA}

Antika AY, Nikmatullah D, dan Prayitno RT. 2017. Tingkat parisipasi anggota P3A dalam program Pengembangan Jaringan Irigasi (PJI) di Kelurahan Fajar Resuk Kecamatan Pringsewu. Jurnal Ilmu Ilmu Agribisnis, 5(3): 335-343. http://jurnal.fp.unila.ac.id/index .php/JIA/article/view/1647/1473. [18 Maret 2020].

BPS [Badan Pusat Statistik] Provinsi Lampung. 2018. Lampung Dalam Angka. BPS Provinsi Lampung. Bandar Lampung.

BPS [Badan Pusat Statistik] Kabupaten Lampung Selatan. 2018. Lampung Selatan Dalam Angka. BPS Kabupaten Lampung Selatan.

Kasogi MI, Lestari DAH, dan Rosanti N. 2014. Manfaat berkelompok tani dalam meningkatkan pendapatan dan efisiensi ekonomi relatif usahatani padi di Desa Negara Ratu Kecamatan Natar Kabupaten Lampung Selatan. Jurnal Ilmu Ilmu Agribisnis, 2(4): 323-

330.https://jurnal.fp.unila.ac.id/index.php/JIA/ article/view/986/892. [18 Maret 2020].

Maulidiawati D, Nikmatullah D, dan Prayitno R.T. 2018. Partisipasi petani dalam program Upsus Pajale di Kecamatan Rawa Jitu
Selatan Kabupaten Tulang Bawang. Jurnal Ilmu Ilmu Agribisnis, 6(1): 65-71. https://jurnal.fp.unila.ac.id/index.php/JIIA /article/view/2500/2184 [18 Maret 2020].

Soekartawi. 2006. Analisis Usahatani. UI Press. Jakarta.

Sugiarto D, Siagian LT, Sunaryanto, Oetomo. 2003. Teknik Sampling. Gramedia Pustaka Utama. Jakarta.

Sugiyono. 2007. Metode Penelitian Kuantitatif dan Kualitatif. Alfabeta. Bandung.

Suroso H. 2014. Faktor-faktor yang mempengaruhi partisipasi masyarakat dalam perencanaan pembangunan di Desa Banjaran Kecamatan Driyorejo Kabupaten Gresik. Jurnal, $17(1)$ : 7. https://www.google.com/url?sa=t\&source=we b\&rct=j\&url=https://media.neliti.com/media/p ublications/40087-ID-faktor-faktor-yangmempengaruhi-partisipasi-masyarakat-dalamperencanaan-pembang [20 Maret 2020].

Triana RS, Rangga KK, dan Viantimala B. 2017. Partisipasi petani dalam program Upaya Khusus Peningkatan Produksi Padi, Jagung, Kedelai (UP2PJK) di Kecamatan Seputih Raman Kabupaten Lampung Tengah. Jurnal Ilmu Ilmu Agribisnis, 5(4): 446-452. http://jurnal.fp.unila.ac.id/index.php/JIA/a rticle/view/1755/1558 [18 Maret 2020].

Yama IMT, Gitosaputro S, dan Hasanudin T. 2018. Partisipasi petani padi dalam pelaksanaan program Peningkatan Produksi Beras Nasional (P2BN) di Kecamatan Seputih Mataram Lampung Tengah. Jurnal Ilmu Ilmu Agribisnis, $\quad$ 6(1): 103-109. http://jurnal.fp.unila.ac.id/index. php/JIA/article/view/2505/2189 [18 Maret 2020] 